\title{
Wiedza jako zasób lokalny w środowisku społecznym wsi. Przypadek rodzin rolniczych
}

\section{Knowledge as a local resource in the rural social environment. A case of agricultural families}

\section{Marcin WÓJCIK}

Uniwersytet Łódzki

Katedra Geografii Regionalnej i Społecznej

ul. Kopcińskiego 31, 900-142 Łódź

marcin.wojcik@geo.uni.lodz.pl

Zarys treści: Artykuł ma na celu wskazanie i opisanie sposobów pozyskiwania oraz przepływu wiedzy w środowisku rolniczym, a także uwarunkowań społeczno-kulturowych tego procesu. Na podstawie przeprowadzonych badań autor wyodrębnia i definiuje dwie płaszczyzny transmisji wiedzy wśród rolników. Szczególnie ważne w tych rozważaniach okazuje się przypisanie rolnika do jego „miejsca”, określane jako swoiste wrośnięcie w ziemię i wynikająca z tego cała wiedza, która powstaje ze współpracy człowieka z tym „miejscem” będąca aktem wieloletniej socjalizacji i doświadczania środowiska. Przepływ wiedzy zawiera się w codziennie wykonywanych czynnościach, obserwacji pracy innych, wymiany poglądów i doświadczeń z członkami wspólnoty lokalnej. Transfer wiedzy w środowisku lokalnym zachodzi również w wyniku relacji pomiędzy „miejscem” życia i pracy rolnika, które zmaterializowane jest w postaci domu rodzinnego i zagrody, a miejscami w otoczeniu. Związki te mają w równym stopniu charakter funkcjonalny i społeczny, a ich efektem jest wytworzenie się zróżnicowanego jakościowo, bo zależnego od poszczególnych biografii, środowiska życia.

Słowa kluczowe: rolnicy, zasoby lokalne, wiedza, „miejsce”.

\section{Wprowadzenie}

Wiedza jest uważana za jeden z najważniejszych czynników przemian społeczno-ekonomicznych. Jej rola wzrasta w procesach usieciowienia, otwierania się poszczególnych „miejsc” na przepływ dóbr, kapitału i ludzi. Stan ciągłego uczenia się, jako pewien akt tworzenia przewagi konkurencyjnej, stanowi coraz częściej główny element w modelu gospodarki opartej na wiedzy oraz kształtowania się specyfiki terytorialnej, którą często nazywa się „regionem uczącym się”. A. Jewtuchowicz (2013, s. 134-135) podkreśla, że „ten proces kreacji zasobów dotyczy nowych kompetencji, umiejętności, szczególnych kwalifikacji, ale także sposobów reakcji aktorów na szybko zachodzące zmiany w ich otoczeniu. Umiejętności i wiedza nie są nabyte raz na zawsze, muszą być stale rozwijane i przekształcane". 
Zdolność ludzi do autokreacji, dostosowania się do warunków, które mogą gwałtownie się zmienić pod wpływem impulsów z przestrzeni globalnej, prowadzi do wytworzenia się specyficznych układów społecznych, w tym zawodowych. Wiedza, jej nabywanie, przekształcanie, jak również dostęp do określonych osiągnięć np. technologicznych, zarządzania procesem, kształtują relacje i struktury społeczne, tworząc nowe „klasy”, których członkowie ze względu na specyfikę współczesnego kształcenia, nazywani są często „klasą kreatywną" (por. Florida 2010). ${ }^{1}$

Zjawisko ciągłego kształcenia i podnoszenie jakości zasobów ludzkich i społecznych dotyczy również środowiska zawodowego rolników. W tym przypadku należy jednak podkreślić, że w warunkach polskich rolnictwo ze względów społeczno-kulturowych (ale również historycznych) ma specyficzny charakter, odmienny niż w państwach przechodzących podobną drogę przemian transformacyjnych. Rolnictwo polskie zachowało w przeważającej mierze rodzinny i wielopokoleniowy charakter, co jest rezultatem procesu dziejowego, w którym olbrzymią rolę odgrywała tożsamość społeczna oparta na stałych wartościach (por. Fedyszak-Radziejowska 1995, 2012).

Wyjaśnienie współczesnych zjawisk kulturowych, w tym kształtowania się specyfiki zasobów lokalnych, wymaga szerokiej interpretacji - geograficznej, historycznej i społecznej. Dużą rolę ogrywa badanie wyobrażeń środowiska życia ludzi. Praca rolnika jako podmiotu tego środowiska o określonej świadomości i wynikającej z niej tożsamości społecznej jest warta zainteresowania, zwłaszcza, że właśnie teraz zachodzą przemiany strukturalne, które określą charakter działalności rolniczej w przyszłości. Mimo zmniejszenia się ekonomicznej roli rolnictwa w gospodarce gospodarstwa rodzinne realizują istotne funkcje, m.in. społeczno-kulturową czy ekologiczną.

Rolnictwo jest dziś jedną z wielu działalności, która określa charakter funkcjonalny, jak również społeczny wsi. Z punktu widzenia przemian kulturowych istotny jest wkład rolnictwa w powstawanie „nowej” wiejskości. W wielu opracowaniach podkreśla się, że dominantą problemową, jak również teoretyczno-metodologiczną powinno być wyjaśnienie specyfiki wiejskiej codzienności. W studiach obszarów wiejskich interesującą propozycję wielowymiarowych badań nad wiejskością zaproponował K. Halfacree (np. 2004, 2009), odwołując się do wcześniejszych prac z zakresu badań przestrzeni społecznej (Lefebvre 1991; Soja 1999). Autor ten zaproponował program badań wsi będący kombinacją trzech perspektyw:

1) wiejskiej lokalności (rural locality), tzn. praktyk (zachowań, działań) o charakterze miejscowym,

2) przedstawień wsi (social representations), tzn. konstrukcji obrazów wsi, głównie zinstytucjonalizowanych,

3) codzienności życia wiejskiego (everyday lives), tzn. form dyskursów o wsi oraz specyficznego doświadczania wiejskiej przestrzeni (por. Wójcik 2012).

W niniejszym opracowaniu rozwijany jest przede wszystkim wątek kształtowania się wiejskiej codzienności, zwłaszcza w zakresie sfery wyobrażeń jako swoistego efektu doświadczenia przestrzeni, a właściwie „miejsc” (wsi), które są otwarte na różne globalne i regionalne uwarunkowania społeczne, kulturowe, polityczne i ekonomiczne (por. Wójcik 2017).

1 Artykuł powstał w ramach projektu finansowanego przez Narodowe Centrum Nauki pt. Modele transferu wiedzy w rolnictwie a efekty produkcyjne gospodarstw rolnych - ujęcie przestrzenne (UMO-2011/01/D/ HS4/03295). 


\section{Cele i metodyka badań}

Celem podjętych badań było wskazanie sposobów pozyskiwania i przepływu wiedzy w środowisku rolniczym, a także uwarunkowań społeczno-kulturowych tego procesu (związanych m.in. z doświadczeniami transformacji ustrojowej oraz przystąpieniem Polski do struktur UE). Z tak sformułowanego celu pracy wynika podstawowy problem badawczy, a mianowicie: w jakim sposób odbywa się transfer wiedzy wśród rolników oraz jakie procesy temu towarzyszą?

Badania przeprowadzono w latach 2012 i 2013, przy użyciu metod jakościowych, z zastosowaniem następujących technik badawczych: wywiadu swobodnego (mało ukierunkowanego) oraz obserwacji uczestniczącej jawnej. Badaniem objęto 10 rodzin rolniczych (dwu, trzypokoleniowych) z trzech województw: mazowieckiego, wielkopolskiego i łódzkiego. Łącznie 25 respondentów. Indywidulany charakter przeprowadzonych prac czynił z wybranych rodzin swoiste studia przypadku. Dla badacza ważne było wówczas, aby do badań pozyskać rodzinne gospodarstwa rolne, a w rozmowach uczestniczyli przedstawiciele różnych pokoleń. W celu lepszego zrozumienia problemu, a także nawiązania bliższej relacji z respondentami, badacz przeciętnie spędzał cały dzień z rodziną biorącą udział w badaniu.

Dobór gospodarstw rolnych do badania był celowy i odbywał się według podobieństwa warunków przyrodniczych, tj. umiejscowienia względem dużej formy morfologii terenu, jaką jest Pradolina Warszawsko-Berlińska. W ten sposób wybrano gospodarstwa o podobnym stanie uwarunkowań przyrodniczych (ogólnie dobrych) w rozwoju rolnictwa, ale jednocześnie o zróżnicowanej przynależności administracyjnej szczebla wojewódzkiego.

Sporządzony w ramach prowadzonych wywiadów plan zagadnień poruszał następujące kwestie:

- informacji ogólnych na temat gospodarstwa rolnego respondenta (położenia gospodarstwa, jego cech produkcyjnych, wielkości, specjalizacji, intensywności produkcji),

- postrzegania przez respondentów obecnej sytuacji rolnictwa w Polsce oraz kondycji własnego gospodarstwa, a także czynników sprzyjających i utrudniających działalność,

- źródeł wiedzy przydatnej w rolnictwie, otoczenia instytucjonalnego,

- wiedzy respondenta na temat rolnictwa, jego relacji z innymi rolnikami,

- opinii badanych na temat przyszłości ich gospodarstwa,

- funkcjonowania rolników w swoich lokalnych społecznościach.

Wybrano technikę wywiadu swobodnego (mało ukierunkowanego), który opiera się na bezpośrednim kontakcie z badanym, jako najbardziej uzasadnioną do postawionych w badaniu celów i problemów badawczych. Jak piszą A. Fontana i J. H. Frey (2009, s. 96) wywiad nieustrukturyzowany ma na celu zrozumienie złożonych zachowań ludzi bez narzucania żadnych apriorycznych kategorii, które mogą zawęzić pole badawcze. Obiektywność metody oparta jest na poszukiwaniu pewnych prawidłowości w opisach problemów, które nakreślają badani. We wszystkich przypadkach poruszano te same zagadnienia, które starano się rozwinąć tak, aby nadać im szeroki kontekst społeczny i kulturowy (por. Frankfort-Nachmias i Nachmias 2001, s. 299; Gudkova 2012, s. 128), a to zaś było szczególnie istotne dla samych badaczy. Natomiast dzięki zastosowaniu obserwacji uczestniczącej można było przyjrzeć się bliżej funkcjonowaniu rodzin rolniczych w ich naturalnym kon- 
tekście, zaobserwować, jak przebiegają procesy komunikacji i jakie relacje panują wśród badanych respondentów. W tabeli 1. przedstawiono rozkład respondentów ze względu na płeć i wiek, zaś w tabeli 2. ze względu na lokalizację gospodarstwa rolnego.

Tabela 1. Płeć i wiek przedstawicieli pokoleń w rodzinach rolniczych

\begin{tabular}{|l|l|l|l|}
\hline Lp. & \multicolumn{1}{|l|}{ Przedstawiciel - pokolenie I } & Przedstawiciel - pokolenie II & Przedstawiciel - pokolenie III \\
\hline 1. & Mężczyzna, 69 & Kobieta, 40 & Mężczyzna, 18 \\
2. & Kobieta, 71 & Mężczyzna, 46 & Kobieta, 21 \\
3. & --------- & Kobieta, 59 & Mężczyzna, 29 \\
4. & Mężczyzna, 68 & Mężczyzna, 45 & Mężczyzna, 19 \\
5. & Mężczyzna, 70 & Mężczyzna, 35 & ---------- \\
6. & Mężczyzna, 58 & Mężczyzna, 36 & Mężczyzna, 16 \\
7. & Kobieta, 83 & ---------- & Mężczyzna, 32 \\
8. & --------- & Mężczyzna, 50 & Kobieta, 25 \\
9. & Mężczyzna, 84 & Mężczyzna, 60 & Mężczyzna, 31 \\
10. & Kobieta, 73 & Mężczyzna, 42 & --------- \\
\hline
\end{tabular}

Źródło: opracowanie własne.

Tabela 2. Lokalizacja gospodarstw rolnych respondentów

\begin{tabular}{|c|c|c|c|}
\hline Lp. & Wieś & Gmina & Województwo \\
\hline 1. & \multirow{2}{*}{$\begin{array}{l}\text { Stary Dębsk } \\
\text { Kozłów Szlachecki }\end{array}$} & \multirow{2}{*}{ Nowa Sucha } & \multirow{2}{*}{ Mazowieckie } \\
\hline 2. & & & \\
\hline 3. & Kompina & Nieborów & \multirow{6}{*}{ Łódzkie } \\
\hline 4. & Boczki & Kocierzew Południowy & \\
\hline 5. & \multirow{2}{*}{$\begin{array}{l}\text { Zduny } \\
\text { Strugienice }\end{array}$} & \multirow{2}{*}{ Zduny } & \\
\hline 6. & & & \\
\hline 7. & \multirow{2}{*}{$\begin{array}{l}\text { Podgórzyce } \\
\text { Marynki }\end{array}$} & \multirow{2}{*}{ Góra św. Małgorzaty } & \\
\hline 8. & & & \\
\hline 9. & \multirow{2}{*}{$\begin{array}{l}\text { Tury } \\
\text { Gąsiorów }\end{array}$} & \multirow{2}{*}{ Kościelec } & \multirow{2}{*}{ Wielkopolskie } \\
\hline 10. & & & \\
\hline
\end{tabular}

Źródło: opracowanie własne.

Przeprowadzone badania pozwoliły wyodrębnić dwie płaszczyzny transferu wiedzy w środowisku rolniczym: pierwsza - w doniesieniu do środowiska rodzinnego rolnika, druga - wspólnoty lokalnej. Obie perspektywy zostaną poniżej szczegółowo scharakteryzowane w oparciu o przywołane fragmenty wywiadów swobodnych z rolnikami. 


\section{Wiedza w środowisku rodzinnym rolnika}

Rolnictwo w Polsce ma wyjątkowy charakter głównie ze względu na specyfikę więzi społecznych występujących w obrębie gospodarstwa rolnego, jak również wewnątrz samej wsi. Rodzina rolnicza stanowi grupę ludzi powiązanych silnymi więzami społecznymi, których życie osobiste i zawodowe toczy się wokół problemów związanych z gospodarowaniem i utrzymaniem się w złożonych warunkach przyrodniczo-antropogenicznych. $Z$ tego punktu widzenia charakter rodziny rolniczej można interpretować w odniesieniu do podwójnej integracji, tj. integracji wokół problemów związanych z działalnością rolniczą oraz integracji wokół „miejsca”, którego głównym ośrodkiem wydaje się być dom rodzinny.

Na skutek zwiększającej się mobilności przestrzennej ludzi jedną z głównych cech współczesnych zmian społecznych stało się pojawianie barier w utrzymaniu ciągłości codziennych bezpośrednich kontaktów w rodzinach. Rodzinne gospodarstwa rolne zachowują w tym znaczeniu jednak tradycyjny charakter, co we współczesnym świecie stwarza z jednej strony warunki do utrzymania głębokich więzi pomiędzy spokrewnionymi osobami, ale z drugiej może być czynnikiem występowania napięć i konfliktów. Sytuację tę opisują kobiety - przedstawicielki średniego pokolenia:

„Praca zbliża, a to że ludzie codziennie wykonują te same rzeczy, jest bardzo ważne. Słyszę, jak ze sobą rozmawiamy. Czasem trudno jest tak do kogoś z rodziny zagadnąć, do dziecka czy do wnuka, a jak jesteśmy razem i myślimy jednocześnie o pracy, to i łatwiej poruszyć trudny temat. Po prostu jest czas na rozmowę, mamy wtedy siebie. Szczególnie latem, dzień jest długi, pracy jest dużo, można pogadać o rzeczach na które nie ma zazwyczaj czasu. Na rodzinę trzeba mieć czas, a pracy jest tyle, że często nie wiem, gdzie mam ręce włożyć, a tak można zrobić i jedno i drugie. Takie coś chyba pomaga wszystkim, no nie wyobrażam sobie, aby spotkać się z synem i wnukami tak od święta albo i w ogóle się nie odzywać całymi dniami, tylko mijać się w progu". (W3,K, 59)

„Wie pan, zdaje sobie sprawę, że bycie razem nie jest łatwe, tacy już jesteśmy. Zawsze było tak, że w domu byli rodzice, ich rodzice, a czasem jeszcze i prababka. Dziś ja jestem pomiędzy, mam dzieci i rodziców. Jak tyle osób jest w domu to zawsze coś się dzieje, cieszę się, że miał mi kto pomóc przy dzieciach, a mam troje. Ale spory też są nieuniknione. Każdy dziś chciałby mieć swój kąt, każdy osobny, i aby nikt mu się nie wtrącał, ale tak u nas się nie da, więc zawsze coś jest na rzeczy. Rodzice narzekają, że dzieci głośno słuchają muzyki, dzieci idą do nas na skargę, że dziadek głośno ogląda telewizję, a czasem to są spory, co kto kupił do lodówki, czego brakuje. Ale myślę, że tak naprawdę, bez tego wszystkiego byłoby bardzo nudno. Życie w takiej rodzinie nie wychowuje egoistów, a później wszystkim jest łatwiej, zwłaszcza uczyć się od siebie, jak się dobrze traktować. Nic nie zastąpi rodziny". (W1,K, 40)

Zarówno intensywność, jak i charakter kontaktów interpersonalnych w wielopokoleniowym domu jest dla badanych rozmówców pewnym przepływem czasu. Na wsi czas regulowany jest cyklami pór roku i związany z charakterem pracy na roli. Mowa o powtarzalności pewnych czynności w okresach odpowiednich prac polowych czy gospodarskich w cyklu tygodniowym. Cykliczność tych działań, ich obserwacja i nauka, a następnie przekazywanie tej wiedzy młodszym, stanowi główny element transferu wiedzy międzypoko- 
leniowej wśród rolników. Choć w układach przestrzennych zagrody są do siebie podobne i każda z nich charakteryzuje się podobnym sposobem przebiegu prac, to wszystkie gospodarstwa rolne można traktować jako „miejsce”, w którym toczą się osobiste i rodzinne historie. Każde gospodarstwo to więc indywidualna historia zakorzenienia, pracy, sukcesów i porażek przesyconych różnymi emocjami. Jeden z rolników sformułował swoje przemyślenia na ten temat w następujący sposób:

„Proszę pana, każda gospodarka i dom to inne dzieje. Mógłbym panu tu całymi dniami opowiadać co się działo, kto miał dużo, później stracił, kto miał szczęście, a kto pecha. Niektóre rodziny tu się skończyły, jakoś tak się złożyło, że albo choroby, albo wyjechali do miast lub na saksy i nie wrócili. A tacy jak my jakoś się trzymamy, choć widzę, że nie zostało nas dużo, tych rolników, co to żywią i bronią. Może i na nas przyjdzie czas, ale mam następców, wnuk mówi, że zostanie, bo lubi tu mieszkać, więc trochę i nadziei jest w tym wszystkim". (W6,M, 58)

Nauka rolnictwa i pozyskiwanie wiedzy w obrębie gospodarstwa jest procesem naturalnym, tzn. młodsze pokolenia, uczestnicząc w codziennej obserwacji czynności wykonywanych przez starsze osoby, podejmują wysiłek powtarzania zadań. Dzieje się to niejako metodą prób i błędów, aż dojdzie do opanowania takiej wiedzy i wykształcenia takich umiejętności, które w konsekwencji pozwolą na samodzielność w pracy i pełne włączenie się w złożony system produkcji. Stanowi to istotny element procesu socjalizacji zarówno pierwotnej, jak i wtórnej. Niemałą rolę odgrywa w tym zakresie właśnie indywidualny, niepowtarzalny charakter każdego gospodarstwa, które samo w sobie jest mikrostrukturą, w obrębie której zachodzą procesy adaptacyjne i poznawcze jednostek. Można powiedzieć, iż rodziny rolnicze mają własną specyfikę socjalizacji, a niebagatelną rolę odgrywa w tym procesie wiedza, którą może dostarczyć nie tylko szkoła, ale przede wszystkim członkowie rodziny. Wiedza ta dotyczy wszelkich cech związanych z użytecznością gospodarstwa, tj. wykorzystaniem sprzętów, pomieszczeń i obiektów, usytuowania względem warunków przyrodniczych (np. stron świata), a także możliwości, które tkwią w ludzkich organizmach, ich wytrzymałości i racjonalnym wykorzystaniu siły fizycznej oraz intelektu. Odnosi się ona także do sprawnego prowadzenia gospodarstwa, a więc powiązana jest z dziedzictwem pokoleń, które latami funkcjonują w tych samych warunkach, zwłaszcza określonych przez struktury fizyczne, kulturowe i biotyczne, swoiste „milieu”. Większą refleksyjnością w tym zakresie charakteryzują się osoby starsze, które proces przekazywania wiedzy opisują jako sentymentalną podróż w czasy, kiedy dojrzewali i wchodzili w dorosłość, co w przypadku rodzin rolniczych, gdzie dzieci w wieku wczesnoszkolnym pomagają w prostych pracach polowych, zachodzi stosunkowo wcześnie. Tak do tej obserwacji odniosła się najstarsza z uczestniczących w badaniu:

„Kiedy już jestem stara i niewiele mogę pomagać w robocie, to często myślę, jak to było kiedyś. Dziś dzieci mają lepsze życie, widzę, jak łatwo wiele dostają. Dawniej była wielka bieda, niewielu się powodziło. Mama i babcia uczyły mnie, jak najlepiej krowę przewiązać, aby wyskubała wszystko co do źdźbła, jak kaczki i gęsi przepędzić, aby nażarły się do syta, z której strony do sadzawki podejść, aby woda była dla zwierzęcia najlepsza. Pamiętam, jak w czasie wojny chowaliśmy jedzenie i zboże, by Niemcy nie mogli nam tego zabrać, a takie schowki były u każdego. Tatuś mój wiedział, jak uprawiać, by z tej małej roli zebrać jak najwięcej. Wie pan, do szkoły za długo się nie chodziło, a czasem nie poszliśmy, bo potrzebna była z nas pomoc. Szkoła była 
u nas, tu się uczyliśmy roli, chyba tak musiało być. Wszyscy mieliśmy jednakowe życia, nikt się nie wyróżniał, nie to co teraz". (W9,K, 84)

Wiedza o własnym gospodarstwie była przez respondentów identyfikowana jako ważny element, bez którego inne czynniki nie mogłyby wypracować dobrych efektów produkcyjnych. Rolnicy podkreślali, że kluczowym warunkiem jest dobra znajomość struktury bonitacyjnej gleb, a także lokalnych stosunków wodnych i wilgotnościowych. Przekazanie wiedzy w tym zakresie od starszych użytkowników gospodarstwa jest procesem długim, ale postrzeganym jako naturalny, który po prostu się dzieje. Wiedza o własnej ziemi jest zatem częścią ogólnej wiedzy rolniczej, a do tego prawdopodobnie elementem w całym systemie jej przepływu, najbardziej niezmiennym. W odniesieniu do tego spostrzeżenia, można przedstawić ciekawą wymianę myśli pomiędzy ojcem i synem:

„Jasne, że życie ciągle robi nam niespodzianki i w rolnictwie tych niespodzianek jest bardzo dużo. Są chyba sytuacje trwałe, a z nich to, co jest u mnie i rzadko się zmienia to ziemia, no i natura. A wielu rzeczy nie dowiem się poza moim gospodarstwem. Przede wszystkim nie dowiem się, jakie wymagania ma moja ziemia, gdzie mogę zasiać odpowiednie zboża, gdzie plony udadzą się, a gdzie nie. Dziś to wszystko jest proste, ale kiedyś pewne rzeczy mnie dziwiły - na przykład, że nie mogę zacząć prac na wiosnę na polu koło domu, tylko jechaliśmy najpierw pod las. Podobnie było latem. Dzieci jeżdżą ze mną, to i się nauczą". (W2,M, 46)

"Chyba już wiem, o co panu chodzi. Nigdy tak nie myślałem, po prostu pracujemy, robimy coś, bo tak tata decyduje, ale rzeczywiście tak jest, jak dziadek i tata mówią. Ja się zatem uczę, ale nigdy nie myślałem, że to szkoła czy coś takiego, tak po prostu jest. Kiedy kazali mi ziemniaki na sadzenie przecinać wzdłuż, zaczynać orkę od miedzy południowej, a nie odwrotnie. Fajnie tak o tym czasem pogadać". (W2,M, 21)

W procesie transferu wiedzy w najbliższym środowisku rolniczym ważny jest także wpływ gospodarstwa na ogólny rozwój umiejętności przydatnych rolnikom. W większości wywiadów podkreślano, że praca w gospodarstwie rolnym oraz funkcjonowanie w wielopokoleniowej rodzinie mają duży wpływ na pomnażanie zasobów wiedzy o charakterze praktycznym. Rolnicy szczególnie podkreślali, że prowadzenie takiego „przedsiębiorstwa” rozwija umiejętności manualne, zmysły, zdolności przewidywania oraz kojarzenia, a także funkcjonowania w grupie. Respondenci często porównywali się z innymi grupami społeczno-zawodowymi, zwłaszcza tymi z miasta, dodając, że współcześnie otaczają ludzi gotowe produkty, a w gospodarstwie wiele rzeczy wytwarza się na własną rękę i przede wszystkim widać sposoby powstawania oraz przetwarzania „wytworów” współpracy człowieka z przyrodą. W tym miejscu nie brakowało również refleksji nad historycznością zjawisk społecznych, ale w narracjach respondentów były one znacząco marginalizowane. Jednocześnie wieś jako miejsce do życia jest postrzegana przez rolników jako przestrzeń pozytywnie wpływająca na komfort funkcjonowania (turystyka weekendowa, drugi obieg żywności). Jeden z rolników z długim stażem zawodowym tak oto opisał swój pogląd w tej sprawie:

„Denerwuje mnie od wielu lat, chyba odkąd mam własne dzieci, że wieś traktuje się jak coś gorszego, a rolników jak jakiś fajtłapy i niepiśmienne sieroty. W ogóle nie chce patrzeć na to, 
co pokazują w telewizji, bo w kółko powtarzają o wsi kłamstwa. A rolnik to wszystko potrafi, wie jak gwoździa wbić, maszynę naprawić, oponę załatać, pospawać, przecież nie będziemy ze wszystkim biegać do fachowca. Mój wnuk, co tu siedzi, zaraz będzie dorosły, a nauczył się wszystkiego, uczciwą pracę znajdzie, bo uczy się w szkole dobrze i jeszcze w gospodarstwie potrafi robić. Mam nadzieję, że tu zostanie, bo w świecie wcale lepiej nie jest, zawsze coś tracą ci, co jadą dalej. Jak była kiedyś trwoga, to wieś żywiła, bo w miastach nic nie było. Dziś też cwaniactwo, przyjeżdżają i myślą, że jak pokażą pieniądze, to im za bezcen ziemię sprzedam. Działki na takiej roli, kto to słyszał, niech gdzieś w górach kupują! ". (W1,M, 69)

\section{Wiedza w środowisku sąsiedzkim rolnika}

Problematyka przemian wiejskich wspólnot lokalnych ciągle jeszcze mieści się w centrum zainteresowań naukowo-badawczych wielu środowisk naukowych. Przykładem są analizy wyników prac społeczności lokalnych w ramach programu LEADER ${ }^{2}$. Niezależnie od oceny samych programów skierowanych na intensyfikację działań społecznych, w efekcie których ma dojść do pogłębienia integracji, należy zauważyć, że wiejskie społeczności mają w dalszym ciągu wystarczający kapitał kulturowy, aby budować realne więzi wewnątrz wspólnot, jak również z terytorium - miejscem zamieszkania. Istotą środowiska lokalnego jest sąsiedztwo i wszystkie uwarunkowania życia społecznego, które z niego wynikają. Większość wsi polskich należy do grupy niedużych osiedli o zwartych układach przestrzennych (dominanty w strukturze osadnictwa wiejskiego). Sama struktura przestrzenna osiedli wiejskiej stwarza większe prawdopodobieństwo rozwoju bezpośrednich relacji społecznych różnego typu. Należy zauważyć, że wsie są często poszerzonymi kręgami bliższych i dalszych kontaktów rodzinnych. Poczucie wspólnoty wydaje się być równie ważne dla wszystkich pokoleń mieszkających na wsi. Jeden z młodych rolników opisał problem kształtowania więzi w następujący sposób:

„Ludzie, zwłaszcza sąsiedzi, muszą ze sobą dobrze żyć, inaczej jest ciągle stres i odgrywanie się. We wsi tej mieszkam od urodzenia i wszystkich tu znam, wiemy o sobie dużo, ale najważniejsze, że mogę liczyć na pomoc innych ludzi. Dużo rodzin utrzymuje się z rolnictwa i to jeszcze zbliża do siebie ludzi, bo problemy mamy podobne". (W5,M, 35)

Pamięć w małych grupach społecznych ma często bardzo intymny wymiar, co jest jednym z czynników kształtujących lokalny charakter dziejów. Wiedza ta dostępna jest najczęściej tylko członkom danej wspólnoty i do tego jest przekazywana w sposób ustny. Źródłem wiedzy o rolnictwie w społeczności lokalnej są przede wszystkim sąsiedzi. Im więcej rolników jest we wsi, tym głębsze relacje wytwarzają się w oparciu o doświadczenia zawodowe, co również wpływa na stopień integracji całej wiejskiej wspólnoty. Wymiana wiedzy ma przede wszystkim charakter relacji „twarzą w twarz” i odbywa się w różnych okolicznościach dnia codziennego. Sąsiedztwo tworzy specyficzny rodzaj dyskursu, w którym istnieje przepływ informacji w różnych kierunkach oraz, jak w każdej wspólnocie, „małego zasięgu”, wiedza powraca do uczestników wymiany, w postaci zniekształconej lub zmienionej. Jeden z rolników tak opisał przykładową sytuację:

\footnotetext{
${ }^{2}$ Por. E. Psyk-Piotrowska i in. (2013).
} 
„Dowiedziałem się od sąsiada, że będą większe dopłaty do paliwa i powtórzyłem to innym. Zapanował wśród nas taki rejwach, że później każdy mówił coś innego, ile to będzie, do ilu hektarów. Kilka dni nie mogliśmy nigdzie tego ustalić, w końcu z gminy przyszła kartka, że jeszcze trzeba poczekać na nowe zasady, a każdy myślał, że już trzeba coś wypełniać". (W5,M, 70)

Sytuacje związane z szumem informacyjnym ze społecznego punktu widzenia mają tę zaletę, że utrwalają i podtrzymują relacje w grupie, co dotyczy bardzo wielu istotnych dla ludzi kwestii związanych z prowadzeniem gospodarstwa domowego czy rolnego. Ważnym elementem tworzenia więzi jest wzajemna obserwacja czynności prowadzonych prac. Wśród rolników, zwłaszcza tych bardziej profesjonalnie podchodzących do działalności gospodarskiej, trwa nieustanna konkurencja, rywalizacja o prymat we wspólnocie oraz o lepsze efekty produkcyjne. Obrazuje to wyścig w pracach polowych, który z jednej strony budzi negatywne emocje, z drugiej zaś stwarza możliwość podpatrywania nowinek technologicznych i w wykorzystaniu środków obrotowych. Wymiana doświadczeń związanych z użytkowaniem nowego sprzętu, wykorzystywaniem nawozów, pasz, itp. jest jednym z najlepszych argumentów w poprawie wyposażenia gospodarstwa oraz w kulturze rolnej. Rolnik prowadzący duże gospodarstwo hodowlane tak przedstawił tę sytuację:

„Pierwsze, co myślę w tym temacie, to że sami robimy najlepszą reklamę, bo jeśli coś jest kiepskie, to nikt tego nie kupi. Wystarczy, że dwóch, trzech powie i reszta już wie, co ma zrobić. Jest też odwrotnie, dobry sprzęt będzie miał innych amatorów. Inna rzecz, to że wiem, do kogo mam pójść po pomoc, wiem, że jak mam problem z cielącą się krową, to zanim przyjedzie weterynarz, to mam kogo tu zaciągnąć, żeby poradził i pomógł. Jak to na wsi, każdy coś potrafi, to i czasem warto porozmawiać lub poprosić. Wszyscy jesteśmy stąd". (W8,M, 50)

\section{Podsumowanie}

Wiedza o środowisku, proces jej nabywania, przechowywania i w konsekwencji przekazywania jest jednym z podstawowych aktów doświadczania świata. W przypadku badań autora tekstu była to wiedza o rolnictwie, ale w całym kontekście zdarzeń życia wiejskiego, z którego wypreparowanie tylko jednego składnika lub ich grupy, stanowiłoby zubożenie interpretacji odnoszącej się do sfery „bycia”. Badania wykazały, że jest to niezwykle złożony i wielowątkowy proces, w którym ważnym czynnikiem sprawczym jest kultura, czyli w dużej mierze pewne wzory myślenia i zachowania. Niebagatelną rolę z tego punktu widzenia odgrywa „umiejscowienie” rolnika oraz jego rodziny, a więc przypisanie do „miejsca”. W tym sensie możemy określić to jako swoiste wrośnięcie w ziemię i wynikająca z tego cała wiedza, która powstaje ze współpracy człowieka z „miejscem” jako akt wieloletniej socjalizacji i doświadczania środowiska. Przepływ wiedzy zawiera się w codziennie wykonywanych czynnościach, obserwacji pracy innych, wymianie poglądów i doświadczeń z członkami wspólnoty lokalnej. Ma on więc bardzo istotny wpływ na zjawisko transmisji kulturowej.

Znaczącą rolę w procesie przekazywania wiedzy odgrywają uwarunkowania społeczne. Gospodarstwa rolne są bardzo dobrym przypadkiem do badania procesów reprodukcji społecznej (odtwarzania struktur społecznych), która zachodzi w układach wielopokoleniowych. Jest to specyficzny rodzaj socjalizacji w środowisku, które jest jednocześnie 
miejscem pracy i życia. Rodzinne gospodarstwo rolne, uznane w Konstytucji RP za podstawę ustroju rolnego państwa, tworzy specyficzne środowisko wymiany wiedzy, w pewien sposób naturalne, tj. przyjmowane bezwarunkowo, i przede wszystkim wpisane w formy materialne „miejsca” - obiekty, sprzęty, w których zawarte jest piętno współczesnych i dawnych pokoleń. Rodzinność i przywiązanie jest związane również ze swoistym odbiorem świata, zwłaszcza najbliższego otoczenia, który każdy ustanawia ma drodze wielu kompromisów pomiędzy uznaniem zasad funkcjonowania wspólnoty (podporządkowanie) oraz postaw indywidualnych, odzwierciedlających współczesne procesy społeczne (autonomia jednostki).

\section{Literatura}

Fedyszak-Radziejowska B. (red.), 1995, Wieś i jej mieszkańcy. Zróżnicowania, postawy i strategie zachowań, IRWiR PAN, Warszawa.

Fedyszak-Radziejowska B., 2012, Społeczności wiejskie: tożsamość, kapitał społeczny, wspólnotowe identyfikacje, [w:] A. Rosner (red.), Społeczne i kulturowe zagadnienia przemian na wsi polskiej, IRWiR PAN, Warszawa, s. 95-118.

Fontana A., Fray J.H., 2009, Wywiad. Od neutralności do politycznego zaangażowania, [w:] N.K. Denzin, Y.S. Lincoln (red.), Metody badań jakościowych, t. 2, Wydawnictwo Naukowe PWN, s. 81-127.

Florida R., 2010, Narodziny klasy kreatywnej, Narodowe Centrum Kultury, Warszawa.

Frankfort-Nachmias Ch., Nachmias D., 2001, Metody badawcze w naukach społecznych, Zysk i S-ka Wydawnictwo, Poznań.

Gudkova S., 2012, Wywiad w badaniach jakościowych, [w:] D. Jemielniak (red.), Badania jakościowe. Metody i narzędzia, Wydawnictwo Naukowe PWN, Warszawa, s. 111-129.

Halfacree K., 2004, Rethinking 'Rurality', [w:] T. Champion, H. Graeme, New Form of Urbanization. Beyond the Urban-Rural Dichotomy, Ashagate, Burlington, s. 285-306.

Halfacree K., 2009, Rurality and post-rurality, [w:]. R. Kitchin, N. Thrift (red.), International Encyclopedia of Human Geography, 9, Elsevier, Amsterdam, s. 449-456.

Jewtuchowicz A., 2013, Terytorium i współczesne dylematy jego rozwoju, Wydawnictwo Uniwersytetu Łódzkiego, Łódź.

Lefebvre H., 1991, The Production of Space, Blackwell Publishing, Carlton, Australia. [oryginalne wydanie: La production de l'espace, 1974].

Psyk-Piotrowska E., Zajda K., Kretek-Kamińska A., Walczak-Duraj D., 2013, Struktura i uwarunkowania kapitału społecznego lokalnych grup działania, Wydawnictwo Uniwersytetu Łódzkiego, Łódź.

Soja E., 1999, Thirdspace: Expending the Scope of the Geographical Imagination, [w:] D.B. Massey, J. Allen, P. Sarre (red.), Human Geography Today, Polity Press, s. 260-278.

Wójcik M., 2012, Geografia wsi w Polsce. Studium zmiany podstaw teoretyczno-metodologicznych, Wydawnictwo Uniwersytetu Łódzkiego, Łódź.

Wójcik M. (red.), 2017, Tożsamość i „miejsce”. Budzenie uśpionego potencjału wsi, Wydawnictwo Uniwersytetu Łódzkiego, Łódź. 


\section{Summary}

The aim of this article is to identify and describe ways of acquiring and transferring knowledge in the agricultural environment, as well as socio-cultural determinants of this process. Based on the research conducted, the author distinguishes and defines two levels of knowledge transmission among farmers. Particularly important in these considerations is the farmer's attribution to his "place", defined as a specific ingrown to the ground and the consequent knowledge that arises from human co-operation with that "place" which is the act of long-term socialization and the experience of the environment. Knowledge transfer is present in everyday activities, observations of others' work, exchange of ideas and experiences with other members of a given local community. Knowledge transfer also occurs as a result of the relationship between a "place" of farmer's life and work, which is manifested as a home and farm, and their surroundings. These relationships are equally functional and social in character, and they result in the development of qualitatively diverse living environment dependent on individual biographies. 
http://rcin.org.pl 